\title{
Nutrient Balance of Layers Fed Diets with Different Calcium Levels and the Inclusion of Phytase and/or Sodium Butyrate
}

Technical Note

-Author(s)
Vieira $\mathrm{MM}^{3}$
Kessler $\mathrm{AM}^{1}$
Ribeiro $\mathrm{AML}^{3}$
Silva ICM
Kunrath $\mathrm{MA}^{2}$
1 UFRGS Professor.
2 Graduate student. Post-Graduation.
Program in Animal Science, UFRGS.
3 UFRGS Professor.

-Mail Adress

Alexandre de Mello Kessler UFRGS Professor

Av. Bento Gonçalves 7712,

91.540-000. Porto Alegre, RS, Brazil.

E-mail: akessler@ufrgs.br

\section{Eeywords}

Bacterial phytase, brown layers, $\mathrm{Ca}$ and $\mathrm{P}$, metabolizability, organic acids.

\begin{abstract}
In this study, Hisex Brown layers in lay were evaluated between 40 and 44 weeks of age to evaluate the inclusion of bacterial phytase (Ph) and sodium butyrate (SB) to diets containing different calcium levels (CaL). Performance, average egg weight and eggshell percentage, in addition to nutrient metabolizability and $\mathrm{Ca}$ and $\mathrm{P}$ balance were evaluated for 28 days. Birds were distributed according to a completely randomized experimental design with a $3 \times 2 \times 2$ factorial arrangement, with three calcium levels $(2.8,3.3,3.8 \%)$; the addition or not of phytase $(500 \mathrm{PhU} / \mathrm{kg})$ and the addition or not of sodium butyrate $(20 \mathrm{mEq} / \mathrm{kg})$, composing 12 treatments with eight replicates of one bird each. There was no additive effect of phytase or SB on the evaluated responses. Feed intake and feed conversion ratio were influenced by $\mathrm{CaL}$, with the best performance obtained with 3.3\% dietary $\mathrm{Ca}$. Ca balance was positively affected by dietary $\mathrm{Ca}$, and $\mathrm{P}$ balance by the addition of phytase. Ca dietary concentration, estimated to obtain $\mathrm{Ca}$ body balance, was $3.41 \%$, corresponding to an apparent retention of $59.9 \%$ of $\mathrm{Ca}$ intake.
\end{abstract}

\section{INTRODUCTION}

Calcium (Ca) requirement estimate for optimal egg production and eggshell quality is 3.25\% (NRC, 1994; Rama-Rao et al., 2003); however, Chandramoni \& Sinha (1998) and Bar et al.(2002) suggest higher requirements, of about 3.6\% Ca. Keshavarz et al. (2003) found even higher needs, of around $3.77 \mathrm{~g} \mathrm{Ca/day} \mathrm{for} \mathrm{optimal} \mathrm{eggshell} \mathrm{synthesis,}$ whereas Leeson \& Summer (2005) suggest 4.2\% Ca, which increases up to $4.6 \%$ dietary $\mathrm{Ca}$ as birds age.

Dietary Ca is essential for eggshell synthesis, and its needs are affected by the stage of eggshell formation (Etches, 1987). Layers actively absorb dietary $\mathrm{Ca}$ for eggshell formation along the entire gastrointestinal tract (Sugiyama et al., 2007). Whereas absolute Ca retention increases with increasing dietary $\mathrm{Ca}$ levels, the efficiency of the absorption process is inversely related to dietary Ca levels (Chandramoni \& Sinha, 1998).

Better egg production was verified in laying hens fed corn-soybean diets supplemented with microbial phytase (Um \& Paik, 1999), which allowed the reduction of dietary phosphate levels with no negative effect on egg production and quality (Camps \& Pérez, 2004). However, other authors did not find any significant influence of microbial phytase supplementation on commercial layer performance (Casartelli, et al. 2005; Liebert et al., 2005), although it has already been shown that the effect of phytase supplementation can be changed by dietary $\mathrm{Ca}$ levels (Lim et al., 2003).

Organic acids had a positive influence on egg production (Gama et al., 2000). Organic acids may also positively affect the intestinal mucosa 
(García et al., 2007) and have a beneficial effect on the intestinal health of poultry (Pirgozliev et al., 2008). The addition of sodium butyrate to poultry diets may stimulate the growth of the duodenal mucosa ( $\mathrm{Hu} \&$ Guo, 2007) and may improve dietary energy availability (Pirgolzliev et al. 2008), thereby improving nutrient absorption.

Nevertheless, the interaction between phytase and organic acids in layers diets is still poorly elucidated. This study aimed at evaluating the addition of sodium butyrate and phytase addition to diets containing different calcium levels on the performance and apparent $\mathrm{Ca}$ and $\mathrm{P}$ retention brown layers.

\section{MATERIALS AND METHODS}

In this study, Hisex Brown layers in lay were evaluated between 40 and 44 weeks of age to evaluate the inclusion of bacterial phytase and sodium butyrate to diets containing different calcium levels.

Birds were housed in individual cages in an environmentally-controlled room since 36 weeks of age and were offered water and feed ad libitum and submitted to a lighting program of $16 \mathrm{~h}$ of light daily.

Diets were formulated according to the levels proposed by Rostagno et al. (2005) for brown layers. The diets were based on corn and soybean meal and contained different $\mathrm{Ca}$ levels $(\mathrm{CaL})$ and addition or not of sodium butyrate (SB) and bacterial phytase (Ph - Quantum ${ }^{\circledR}$ 2500, ABEnzymes) (Table 1). Birds were distributed according to a completely randomized experimental design with a $3 \times 2 \times 2$ factorial arrangement, with three calcium levels (2.8, $3.3,3.8 \%$ ); the addition or not of $500 \mathrm{PhU} / \mathrm{kg}$ of phytase (as recommended by the manufacturer); and the addition or not of $20 \mathrm{mEq} / \mathrm{kg}$ sodium butyrate, composing 12 treatments with eight replicates of one bird each, totaling 96 experimental units (Table 2). Available phosphorus level was estimated as $0.40 \%$ in all experiment diets, which required the reduction of total phosphorus content in diets containing phytase equivalent to the enzyme contribution of $0.13 \%$ available P/kg diet, according to the manufacturer.

Total excreta collection was performed during the entire experimental period (40 to 44 weeks of age) to calculate nutrient metabolizability and mineral balance responses. Comparative slaughter of bird carcasses in the beginning and at the end of the experimental period was used to obtain body nutrient balance responses. Analyses of dry matter, ash, and nitrogen in the diets, excreta and carcasses, and of crude fat in the carcasses were performed according to the methods of the AOAC (1993). Gross energy of diets, excreta, and carcasses was determined using an isoperibolic bomb calorimeter (IKA WERKE, model C2000). Ca and $P$ analyses in feeds and excreta were carried out using atomic absorption spectrophotometry and colorimetry, according to the specifications of Tedesco et al. (1995).

Table 1 - Basal diet composition and calculated nutritional composition of the diets fed to brown layers between 40 and 44 weeks of age.

\begin{tabular}{|c|c|}
\hline Ingredients & $\%$ \\
\hline \multicolumn{2}{|l|}{ Basal diet } \\
\hline Corn & 58.73 \\
\hline Soybean meal & 25.37 \\
\hline Vegetable fat & 3.40 \\
\hline Salt & 0.47 \\
\hline DL-Methionine, \% & 0.24 \\
\hline Choline-Cl, \% & 0.07 \\
\hline L-Lysine $\mathrm{HCl}, \%$ & 0.03 \\
\hline Mineral premix ${ }^{1}$ & 0.06 \\
\hline Vitamin premix ${ }^{2}$ & 0.03 \\
\hline Treatments 3 & 11.60 \\
\hline \multicolumn{2}{|l|}{ Calculated composition } \\
\hline Metabolizable energy (kcal/kg) & 2900 \\
\hline Crude protein (\%) & 16.6 \\
\hline Digestible methionine (\%) & 0.46 \\
\hline Digestible lysine (\%) & 0.75 \\
\hline Digestible methionine+cystine (\%) & 0.70 \\
\hline Digestible threonine (\%) & 0.60 \\
\hline Digestible tryptophan (\%) & 0.17 \\
\hline Digestible arginine (\%) & 0.91 \\
\hline Sodium (\%) & 0.20 \\
\hline Chloride (\%) & 0.31 \\
\hline Potassium (\%) & 0.70 \\
\hline Calcium $(\%)^{4}$ & $2.8 ; 3.3 ; 3.8$ \\
\hline Total phosphorus (\%) & $0.48 ; 0.61$ \\
\hline Available phosphorus (\%) & 0.40 \\
\hline \multicolumn{2}{|c|}{$\begin{array}{l}1 \text { - Addition per kg diet: selenium } 0.3 \text { mg; iodine } 0.7 \text { mg; iron } 40 \text { mg; } \\
\text { copper } 10 \text { mg; zinc } 80 \text { mg; manganese } 80 \text { mg; } 2 \text { - Addition per kg diet: } \\
\text { Vit A } 8000 \text { IU; Vit D3 } 2000 \text { IU; Vit E } 30 \text { mg; Vit K } 2 \text { mg; Vit B1 } 2 \text { mg; Vit } \\
\text { B2 } 6 \text { mg; Vit B6 } 2.5 \text { mg; Vit B12 } 0.012 \text { mg; biotin } 0.08 \text { mg; pantothenic } \\
\text { acid } 15 \text { mg; niacin } 35 \text { mg; folic acid } 1 \text { mg. } 3 \text { - Calcium, sodium butyrate } \\
\text { and phytase levels according to treatment. } 4 \text { - Different according to } \\
\text { experimental diets. }\end{array}$} \\
\hline
\end{tabular}

The following performance parameters were evaluated for the $28 \mathrm{~d}$ experimental period: daily feed intake, feed conversion ratio per dozen eggs and per egg mass, egg production, average egg weight, and average eggshell percentage (dried at $105^{\circ} \mathrm{C}$ ). The metabolizability of dry matter (DMM), organic matter (OMM), mineral matter (MMM), crude protein (CPM) and gross energy (GEM) expressed as intake percentage; $\mathrm{Ca}$ balance $(\mathrm{CaB})$ and $\mathrm{P}$ balance $(\mathrm{PB})$ expressed in absolute ( $g /$ day) and relative (intake 
percentage) values; $\mathrm{Ca}$ and $\mathrm{P}$ intake and excretion in g/day; Ca eggshell content (CaShell) on g/day and intake percentage (CaShell\%) and $\mathrm{Ca}$ body balance in $\mathrm{mg} /$ day $(\mathrm{CaBB}=\mathrm{Ca}$ intake $-\mathrm{Ca}$ excretion $-\mathrm{Ca}$ in the eggshell) were evaluated. In addition, the nutrient body balance of minerals (MBB), protein (PBB), fat (FBB) were calculated and expressed in $\mathrm{g} /$ day, as well as and energy body balance (EBB), expressed in kcal/ day.

Table 2 - Composition of the experimental diets containing different calcium levels and the addition or not of phytase and/or sodium butyrate fed to brown layers between 40 and 44 weeks of age.

\begin{tabular}{|c|c|c|c|c|c|c|}
\hline Calcium levels (\%) & 2.8 & 2.8 & 3.3 & 3.3 & 3.8 & 3.8 \\
\hline Total phosphorus (\%) & 0.61 & 0.48 & 0.61 & 0.48 & 0.61 & 0.48 \\
\hline \multicolumn{7}{|l|}{ Ingredients (\%) } \\
\hline Calcitic limestone & 6.48 & 6.92 & 7.87 & 8.31 & 9.27 & 9.70 \\
\hline Dicalcium phosphate & 1.73 & 1.00 & 1.73 & 1.00 & 1.73 & 1.00 \\
\hline Kaolin & 2.79 & 3.06 & 1.40 & 1.67 & - & 0.28 \\
\hline Phytase & - & 0.02 & - & 0.02 & - & 0.02 \\
\hline Sodium butyrate/ Starch ${ }^{1}$ & 0.60 & 0.60 & 0.60 & 0.60 & 0.60 & 0.60 \\
\hline
\end{tabular}

The statistical model was submitted to analysis of variance using the GLM procedure of SAS statistical package (1999). The means of the main factors and interactions were compared by the test of Student-

Table 3 - Feed intake (FI), feed conversion ratio (FCR), egg production (EPr) (EPr), average egg weight (AEW) and average eggshell percentage (ES\%) of brown layers fed diets containing different calcium levels and the addition or not of phytase and/ or sodium butyrate between 40 and 44 weeks of age.

\begin{tabular}{lcccccc}
\hline & Fl(g/d) & FCR(kg/dz) & FCR(kg/kg) & EPr(\%) & AEW(g) & ES\% \\
\hline Calcium levels (CaL) & & & & & & \\
\hline $2.8 \%$ & $117.9 a^{*}$ & $1.379 a$ & $1.767^{\mathrm{a}}$ & 96.0 & 65.37 & 9.57 \\
$3.3 \%$ & $112.3 \mathrm{~b}$ & $1.288 \mathrm{~b}$ & $1.645 \mathrm{~b}$ & 97.4 & 65.35 & 9.66 \\
\hline $3.8 \%$ & $119.8 \mathrm{a}$ & $1.390 \mathrm{a}$ & $1.746^{\mathrm{a}}$ & 97.0 & 66.13 & 9.71 \\
\hline Sodium butyrate (SB) & & & & & & \\
\hline 0 & 116.0 & 1.344 & 1.718 & 96.5 & 65.18 & 9.60 \\
\hline 20 meq/kg & 117.4 & 1.361 & 1.721 & 97.1 & 66.04 & 9.70 \\
\hline Phytase (Ph) & & & & & & \\
\hline 0 & 118.4 & 1.379 & 1.751 & 96.3 & 65.23 & 9.68 \\
\hline 500 PhU/kg & 115.0 & 1.325 & 1.687 & 97.3 & 66.00 & 9.62 \\
\hline Probability & & & & & & \\
\hline CaL & 0.028 & 0.015 & 0.048 & 0.465 & 0.424 & 0.691 \\
SB & 0.536 & 0.591 & 0.947 & 0.596 & 0.113 & 0.498 \\
Ph & 0.161 & 0.083 & 0.140 & 0.266 & 0.160 & 0.674 \\
CaLxSB & 0.644 & 0.721 & 0.786 & 0.438 & 0.717 & 0.856 \\
CaLxPh & 0.759 & 0.866 & 0.984 & 0.178 & 0.894 & 0.295 \\
\hline SBxPh & 0.459 & 0.183 & 0.093 & 0.189 & 0.368 & 0.582 \\
CaLxSBxPh & 0.671 & 0.604 & 0.060 & 0.804 & 0.005 & 0.486 \\
SEM & 10.963 & 0.143 & 0.200 & 4.499 & 3.849 & 0.650 \\
\hline
\end{tabular}

* Means followed by different letters in the same column are significantly different (SNK $\mathrm{p}<0.05)$.
Newman-Keuls at $5 \%$ probability levels. The effects of dietary calcium levels were tested by analysis of regression.

\section{RESULTS AND DISCUSSION}

The statistical analysis of performance responses (Table 3) showed that the treatments influenced only feed intake, feed conversion ratio and average egg weight $(p<0.05)$. There were no significant interactions for feed intake and feed conversion ratio $(p>0.05)$. As to the main effects, only dietary calcium levels affected performance (Table 3). The level of $3.3 \%$ Ca resulted in lower feed intake, and considering that egg production was similar among treatments, feed conversion ratio was better. This result is consistent with those of Keshavarz (2003), who observed that $3.34 \%$ dietary calcium resulted in adequate performance and eggshell quality in layers after 45 weeks of age, while Chandramoni \& Sinha (1998) found that 3.6g/day resulted in optimal daily egg production during lay.

Average egg weight was significantly affected by the interaction among the three studied factors $(p<0.005)$ : at $3.8 \% \mathrm{Ca}$ and in when both additives were present in the diet, egg weight was statistically higher $(68.2 \mathrm{~g})$ than in treatment containing only $\mathrm{Ph}$ $(64.6 \mathrm{~g})$ or SB $(64.7 \mathrm{~g})$, but similar to the diet with no additives (67.0g), which therefore does not confer any practical application to this interaction. On the other hand, the treatments did not affect egg production, differently from the findings of Um and Paik (1999), who used phytase, and of Gama et al. (2000), who used an organic acid blend (fumaic, lactic, citric, and ascorbic acids). Eggshell percentage was not affected by the studied factors, which is in agreement with the results of Lichovnicova (2007), but not with those of Casartellli et al. (2005).

There was no effect of sodium butyrate or phytase on calcium balance (Table 4). However, dietary $\mathrm{Ca}$ levels affected $\mathrm{Ca}$ intake, with a linear and positive effect on relative $\mathrm{Ca}$ balance (in $\mathrm{g}$ ) and on $\mathrm{Ca}$ content in the excreta. Calcium levels affected $\mathrm{CaB}$ both in $\mathrm{g} /$ day and as intake percentage. Linear equations of $\mathrm{Ca}$ balance and excretion showed that $\mathrm{Ca}$ excretion increased $0.89 \mathrm{~g} /$ day, whereas Ca balance increased $0.41 \mathrm{~g} /$ day per one percentage 
point of $\mathrm{Ca}$ increase in the diet. Therefore, there was a decreasing effect on Ca retention efficiency as $\mathrm{Ca}$ dietary levels increased, which was also found by Chandramoni \& Sinha (1998). Moreover, Ca deposition in the eggshell, in g, was similar among diets, which is consistent with the results of Lichovnicova (2007), but the efficiency of $\mathrm{Ca}$ deposition in the eggshell as a percentage of intake decreased as dietary $\mathrm{Ca}$ increased. Eggshell formation was maintained with the lowest dietary $\mathrm{Ca}$ levels, but at the expense of bone $\mathrm{Ca}$, resulting in a negative body $\mathrm{Ca}$ balance, as shown by the data ( $\mathrm{CaBB})$.

The results of the present study show important features of Ca metabolism in layers and its effects on Ca requirements: at low dietary levels, birds maximize dietary $\mathrm{Ca}$ utilization, reducing their excretion. As dietary $\mathrm{Ca}$ increases, it higher availability is directly related to higher $\mathrm{Ca}$ excretion and, at the same time, bone loss is prevented. In the present experiment, when egg production was maintained, Ca body balance was the best indicator of dietary calcium requirements. The equation $\mathrm{Ca}$ body balance $=-1.065+0.312 * \mathrm{CL}$ $\left(p<0.001 ; R^{2}=0.255\right)$ indicated that level of $3.41 \%$ dietary $\mathrm{Ca}$ is necessary to optimize $\mathrm{Ca}$ body balance. When this level is applied in the equation $\mathrm{Ca} \%$ in the eggshell $=122.46-18.326{ }^{*} \mathrm{CL}\left(p<0.001 ; R^{2}=0.691\right)$, the efficiency of $\mathrm{Ca}$ retention in the egg was $59.9 \%$, and apparent Ca retention was 59\%, as determined by the equation Ca balance $\%=88.667-8.673{ }^{*} \mathrm{CL}$ $\left(p<0.001 ; R^{2}=0.194\right)$. These values are similar to that of $54.2 \%$ proposed by Georgievskii (1982) for 3.08 $\mathrm{g} / \mathrm{d}$ intake, of $57.8 \%$ measured by Lichovnicova (2007) with a diet containing $4.08 \% \mathrm{Ca}$; and of $56.1 \%$ estimated by Kebreab (2009) with a diet with 3.5\% $\mathrm{Ca}$. Even considering that different dietary $\mathrm{Ca}$ levels were used in the different experiments and that $\mathrm{Ca}$ levels affect the efficiency of apparent retention, the value close to $60 \%$ possibly represent the maximum physiological limit of dietary Ca utilization with no impairment of body functions.

The addition of phytase significantly influenced $P$ balance, leading to lower $P$ intake and excretion, consequently improving the efficiency of $P$ retention, although not significantly $(p<0.063)$ (Table 5$)$. Better efficiency of $\mathrm{Ca}$ and $\mathrm{P}$ retention was observed by Um \& Paik (1999) with the use of phytase. However, in the present experiment, $\mathrm{P}$ balance (PB) was lower, which was expected because the diets containing phytase had lower total $\mathrm{P}$ content. According to Liebert et al. (2005), the addition of phytase to layer diets did not affect $\mathrm{P}$ excretion, whereas Casartelli et al. (2005) found reduced $\mathrm{P}, \mathrm{Ca}$ and $\mathrm{N}$ excretion with $1000 \mathrm{PhU/}$ $\mathrm{kg}$. Considering that the level of available $P$ was similar among the experimental diets, the results confirm the

Table 4 - Ca intake, excretion and balance expressed in g/day and as intake percentage, Ca in the eggshell (g/day and intake percentage) and $\mathrm{Ca}$ body balance (mg/day of brown layers fed diets containing different calcium levels and the addition or not of phytase and/or sodium butyrate between 40 and 44 weeks of age.

\begin{tabular}{|c|c|c|c|c|c|c|c|}
\hline & Ca intake(g/d) & Ca $\operatorname{excr}^{1}(g / d)$ & $\mathrm{CaB}^{2}(\mathrm{~g} / \mathrm{d})$ & $\mathrm{CaB}^{3}(\%)$ & $\mathrm{CaES}^{4}(\mathrm{~g})$ & $\mathrm{CaES}^{5}(\%)$ & $\mathrm{CaBB}^{6}(\mathrm{mg} / \mathrm{d})$ \\
\hline \multicolumn{8}{|l|}{ Ca level } \\
\hline $2.8 \%$ & $3.26^{a}$ & $1.15^{\mathrm{a}}$ & $2.11^{\mathrm{a}}$ & $64.75^{a}$ & 2.33 & $71.72^{\mathrm{a}}$ & $-184.6^{a}$ \\
\hline $3.3 \%$ & $3.93 b$ & $1.60 \mathrm{~b}$ & $2.32 b$ & $59.34^{\mathrm{a}}$ & 2.37 & $60.85 b$ & $-49.3 b$ \\
\hline $3.8 \%$ & $4.53 c$ & $1.99 c$ & $2.54 \mathrm{c}$ & $56.19 b$ & 2.43 & $53.46 c$ & $128.2 \mathrm{c}$ \\
\hline \multicolumn{8}{|c|}{ Sodium butyrate } \\
\hline 0 & 3.86 & 1.55 & 2.31 & 60.45 & 2.35 & 62.65 & -30.4 \\
\hline $20 \mathrm{meg} / \mathrm{kg}$ & 3.95 & 1.61 & 2.34 & 59.73 & 2.40 & 62.02 & -51.8 \\
\hline \multicolumn{8}{|l|}{ Phytase (Ph) } \\
\hline 0 & 3.89 & 1.57 & 2.32 & 59.96 & 2.38 & 62.54 & -32.1 \\
\hline $500 \mathrm{FTU} / \mathrm{kg}$ & 3.91 & 1.59 & 2.33 & 60.21 & 2.37 & 62.13 & -50.0 \\
\hline \multicolumn{8}{|l|}{ Probability } \\
\hline $\mathrm{CaL}$ & 0.001 & 0.001 & 0.001 & 0.001 & 0.151 & 0.001 & 0.001 \\
\hline SB & 0.188 & 0.351 & 0.704 & 0.654 & 0.250 & 0.734 & 0.625 \\
\hline $\mathrm{Ph}$ & 0.759 & 0.805 & 0.956 & 0.875 & 0.823 & 0.843 & 0.622 \\
\hline $\mathrm{CaL} \times \mathrm{SB}$ & 0.440 & 0.523 & 0.965 & 0.776 & 0.946 & 0.439 & 0.869 \\
\hline $\mathrm{CaL} \times \mathrm{Ph}$ & 0.644 & 0.414 & 0.462 & 0.515 & 0.454 & 0.971 & 0.454 \\
\hline $\mathrm{SB} \times \mathrm{Ph}$ & 0.219 & 0.199 & 0.924 & 0.309 & 0.315 & 0.997 & 0.244 \\
\hline $\mathrm{CaL} \times \mathrm{SB} \times \mathrm{Ph}$ & 0.510 & 0.252 & 0.161 & 0.200 & 0.274 & 0.592 & 0.513 \\
\hline SEM & 0.316 & 0.325 & 0.301 & 7.375 & 0.178 & 5.179 & 0.225 \\
\hline
\end{tabular}

*Means followed by different letters in the same column are significantly different (SNK $p<0.05) .1-$ Ca excretion $=-1.355+0.8856 * C a L\left(p<0.001 ; R^{2}=\right.$ 0.570). 2 - Ca balance $=0.979+0.412 * C a L\left(p<0.001 ; R^{2}=0.257\right) .3-$ Ca balance $\%=88.667-8.673 * C a L\left(p<0.001 ; R^{2}=0.194\right) .4-C a$ in the eggshell $g=2.045+0.099 * C a L\left(p<0.04 ; R^{2}=0.052\right) .5-C a$ in the eggshell $\%=122.46-18.326 * a C L\left(p<0.001 ; R^{2}=0.691\right) .6-C a$ body balance $=-1.065+$ $0.312{ }^{*} \mathrm{CaL}\left(p<0.001 ; R^{2}=0.255\right)$. 
positive action of phytase both on the excretion and on the efficiency of $P$ retention, showing that these diets promoted the utilization of phosphorus derived from phytate and made available by phytase. Table 5 shows that neither calcium levels nor sodium butyrate influenced $P$ balance responses.

Table 5 - P intake (PInt), P excretion (PExcr) and P balance (PB), expressed in $\mathrm{mg} /$ day and $\mathrm{P}$ balance expressed as intake percentage of brown layers fed diets containing different calcium levels and the addition or not of phytase and/or sodium butyrate between 40 and 44 weeks of age.

\begin{tabular}{|c|c|c|c|c|}
\hline & PInt (mg/d) & PExcr (mg/d) & PB (mg/d) & PB (\%) \\
\hline \multicolumn{5}{|c|}{ Calcium level (CaL) } \\
\hline $2.8 \%$ & 630.4 & 404.6 & 225.7 & 35.97 \\
\hline $3.3 \%$ & 645.7 & 421.4 & 224.3 & 34.67 \\
\hline $3.8 \%$ & 645.0 & 422.1 & 228.9 & 34.70 \\
\hline \multicolumn{5}{|c|}{ Sodium butyrate (SB) } \\
\hline 0 & 633.6 & 411.1 & 222.9 & 35.29 \\
\hline $20 \mathrm{meq} / \mathrm{kg}$ & 646.8 & 421.1 & 225.7 & 34.93 \\
\hline \multicolumn{5}{|l|}{ Phytase (Ph) } \\
\hline 0 & $715.4 a^{*}$ & $471.1 a$ & $244.3^{a}$ & 34.05 \\
\hline $500 \mathrm{FTU} / \mathrm{kg}$ & $565.4 b$ & $360.7 b$ & $204.3 b$ & 36.17 \\
\hline \multicolumn{5}{|l|}{ Probability } \\
\hline CaL & 0.430 & 0.232 & 0.958 & 0.547 \\
\hline SB & 0.244 & 0.297 & 0.728 & 0.750 \\
\hline $\mathrm{Ph}$ & 0.001 & 0.001 & 0.001 & 0.063 \\
\hline $\mathrm{CaL} \times \mathrm{SB}$ & 0.479 & 0.968 & 0.373 & 0.464 \\
\hline $\mathrm{CaL} \times \mathrm{Ph}$ & 0.575 & 0.805 & 0.579 & 0.698 \\
\hline $\mathrm{SB} \times \mathrm{Ph}$ & 0.342 & 0.326 & 0.897 & 0.672 \\
\hline $\mathrm{CaL} \times \mathrm{SB} \times \mathrm{Ph}$ & 0.589 & 0.974 & 0.382 & 0.509 \\
\hline SEM & 0.052 & 0.045 & 0.039 & 5.251 \\
\hline
\end{tabular}

* Means followed by different letters in the same column are significantly different (SNK $p<0.05)$.
Nutrient metabolizability responses were not different as a function of the main effects studied (Table 6). In addition, there was no interaction among $\mathrm{CaL}, \mathrm{Ph}$ or SB on nutrient utilization.

Nutrient body balance was not affected by the different diets, but, in average, there was negative body balance of minerals and protein with all experimental diets, independently of the tested factors. This somewhat reflects the high egg production observed during the experimental period, when birds used their mineral and protein body reserves for egg production, but presented, compensatorily, body fat and energy gain.

\section{CONCLUSION}

Phytase and sodium butyrate did not affect the performance or nutrient metabolizability of layers in lay. Phytase improved $\mathrm{P}$ apparent retention. The lowest dietary Ca level promoted the best Ca apparent retention, but resulted in negative $\mathrm{Ca}$ body balance. The estimated concentration of dietary Ca for Ca body balance was $3.41 \%$ de Ca.

\section{REFERENCES}

Association of Official Agricultural Chemistis. Official methods of analysis. 16th ed. Washington; 1993. 1160p.

Bar A, Razaphphkovsky V, Vax E. Re-evaluation of calcium and phosphorus requirements in aged laying hens. British Poultry

Table 6 - Metabolizability of dry matter (DMM), organic matter (OMM), mineral matter (MMM), crude protein (CPM) and gross energy $(\mathrm{GEM})$, and body balance of minerals (MBB), protein (PBB), fat (FBB) and energy (EBB) of brown layers fed diets containing different calcium levels and the addition or not of phytase and/or sodium butyrate between 40 and 44 weeks of age.

\begin{tabular}{|c|c|c|c|c|c|c|c|c|c|}
\hline & DMM \% & OMM \% & MMM \% & CPM \% & GEM \% & MBB $\mathrm{mg} / \mathrm{d}$ & PBB $\mathrm{mg} / \mathrm{d}$ & FBB g/d & EBB kcal/d \\
\hline \multicolumn{10}{|c|}{ Calcium level (CaL) } \\
\hline $2.8 \%$ & 72.07 & 77.23 & 41.28 & 47.86 & 80.13 & -348 & -96.8 & 2.28 & 20.9 \\
\hline $3.3 \%$ & 72.01 & 77.14 & 41.42 & 46.87 & 79.75 & -308 & -236 & 2.35 & 20.6 \\
\hline $3.8 \%$ & 72.30 & 77.59 & 40.38 & 46.60 & 79.97 & -277 & -12.1 & 2.86 & 26.6 \\
\hline \multicolumn{10}{|c|}{ Sodium butyrate (SB) } \\
\hline 0 & 71.90 & 77.06 & 40.80 & 47.16 & 79.59 & -293 & -36.1 & 2.31 & 21.4 \\
\hline $20 \mathrm{meq} / \mathrm{kg}$ & 72.35 & 77.59 & 41.25 & 47.06 & 80.31 & -331 & -200 & 2.66 & 23.7 \\
\hline \multicolumn{10}{|c|}{ Phytase (Ph) } \\
\hline 0 & 72.02 & 77.12 & 41.46 & 46.82 & 79.77 & -301 & -303 & 2.40 & 20.5 \\
\hline 500FTU/kg & 72.24 & 77.52 & 40.60 & 47.40 & 80.13 & -324 & 60.4 & 2.57 & 24.6 \\
\hline \multicolumn{10}{|l|}{$P$} \\
\hline CaL & 0.903 & 0.742 & 0.756 & 0.578 & 0.782 & 0.435 & 0.802 & 0.509 & 0.421 \\
\hline SB & 0.413 & 0.279 & 0.704 & 0.927 & 0.120 & 0.366 & 0.517 & 0.402 & 0.581 \\
\hline $\mathrm{Ph}$ & 0.693 & 0.421 & 0.475 & 0.584 & 0.435 & 0.616 & 0.185 & 0.719 & 0.320 \\
\hline CaLxSB & 0.850 & 0.694 & 0.665 & 0.677 & 0.837 & 0.462 & 0.634 & 0.582 & 0.390 \\
\hline CaLxPh & 0.771 & 0.878 & 0.409 & 0.979 & 0.901 & 0.150 & 0.987 & 0.381 & 0.416 \\
\hline SBxPh & 0.346 & 0.450 & 0.235 & 0.615 & 0.328 & 0.161 & 0.978 & 0.853 & 0.899 \\
\hline CaLxSBxPh & 0.624 & 0.829 & 0.124 & 0.483 & 0.761 & 0.176 & 0.560 & 0.091 & 0.240 \\
\hline SEM & 2.56 & 2.30 & 5.59 & 4.901 & 2.14 & 0.19 & 1.22 & 1.87 & 17.89 \\
\hline
\end{tabular}


Science 2002; 43:261-269.

Casartelli EM, Junqueira OM, Laurentiz AC, Filardi RS, Lucas Junior J, Araújo LF. Effect of phytase in laying hen diet whith different phosphorus sources. Revista Brasileira de Ciência Avícola 2005; 7(2):93-98.

Chandramoni SBJ, Sinha RP. Effect of dietary calcium and phosphorus concentration on retention of these nutrients by caged layers. British Poultry Science 1998; 39:544-548.

Camps DM, Pérez J. Utilización de fitasa en la dieta para ponedoras White Leghorn. Revista Cubana de Ciência Avícola 2004; 28:1-4.

Etches RJ. Calcium logistics in the laying hen. Journal of Nutrition 1987; 117:619-628.

Gama NMSQ, Oliveira MBC, Santin E, Berchieri Jr A. Ácidos orgânicos em rações de poedeiras comerciais. Ciência Rural 2000; 30(3):499-502.

García V, Catalá-Gregori P, Hernandéz F, Megías MD, Madrid J. Effect of formic acid and plant extracts on growth, nutrient digestibility, intestine mucosa morphology, and meat yield of broilers. Journal of Applied Poultry Research 2007; 16:555-562.

Hu Z, Guo Y. Effects of dietary sodium butyrate supplementation on the intestinal morphological structure, absorptive function and gut flora in chickens. Animal Feed Science and Technology 2007; $132: 240-249$

Keshavarz KA. Comparison between cholecalciferol and 25-OHcholecalciferol on performance and eggshell quality of hens fed different levels of calcium and phosphorus. Poultry Science 2003; 82:1415-1422.

Leeson S, Summer J. Comercial poultry nutrition. $3^{\text {rd }}$ ed. Guelph: University Books; 2005. $411 \mathrm{p}$.

Lichovnikova M. The effect of dietary calcium source, concentration and particle size on calcium retention, eggshell quality and overall calcium requirement in laying hens. British Poultry Science 2007; 48(1):71-75.

Lim HS, Namkung H, Paik IK. Effects of phytase supplementation on the performance, egg quality, and phosphorous excretion of laying hens fed different levels of dietary calcium and nonphytate phosphorous. Poultry Science 2003; 82:92-99.

Liebert F, Htoo JK, Sünder A. Performance and nutrient utilization of laying hens fed low-phosphorus corn-soybean and wheat-soybean diets supplemented with microbial phytase. Poultry Science 2005; 84:1576-1583

National Research Council. Nutrient requirements of poultry. $9^{\text {th }}$ ed. Washington, D.C.: National Academic Press; 1994. 155p.

Pirgozliev V, Murfhy TC, Owens B, George J, McCann MEE. Fumaric and sorbic acis as additives in broiler feed. Research in Veterinary Science 2008; 84:387-394.

Rama Rao SV, Panda AK, Raju MVLN, Shyam Sunder G, Praharaj NK. Requirement of calcium for commercial broilers and white leghorn layers at low dietary phosphorus levels. Animal Feed Science and Technology 2003; 106:199-208.

Rostagno HS, Albino LFT, Donzelle JL, Gomes PC, Oliveira RF, Lopes DC, Ferreira AS, Barreto SLT. Tabelas brasileiras para aves e suínos: composição de alimentos e exigências nutricionais. $2^{\circ}$ ed. Viçosa: UFV, Departamento de Zootecnia; 2005. 186p.

SAS Institute. SAS/STAT user's guide. Cary, NC: SAS Institute; 1999. 943p.

Sugiyama T, Kikuchi H, Hiyama S, Nishizawa K, Kusuhara S. Expression and localisation of calbindin D28k in all intestinal segments of the laying hen. British Poultry Science 2007; 48(2): 233-238.

Tedesco MJ, Gianello C, Bissani CA, Bohnen H, Volkweiss SJ. Análises de solos, plantas e outros materiais. $2^{\circ}$ ed. Porto Alegre: Departamento de Solos da UFRGS; 1995. 174p.

Um JS, Paik IK. Effects of microbial phytase supplementation on egg production, eggshell quality, and mineral retention of laying hens fed different levels of phosphorus. Poultry Science 1999; 78: 75-7. 